\title{
DISCURSO DE POSSE DO DIRETOR DA ESCOLA DE EDUCAÇÃO FÍSICA DA UNIVERSIDADE DE SÃO PAULO
}

\author{
Prof. Dr. Erasmo Magalhāes Castro de Tolosa
}

Assumo a função de Diretor da Escola de Educaçāo Física da Universidade de São Paulo consciente da pesada missão que esta escola e o Magnífico Reitor assim determinaram.

Estou certo, Magnífico Reitor, das dificuldades que irei enfrentar na condução dos destinos da Escola de Educação Física; contudo, como diria Cervantes, "Contento-me com pouco, mas desejo muito." Do ponto de vista pessoal acrescentarei às minhas múltiplas atividades, unicamente dentro da Universidade de São Paulo, essa considerável e importante tarefa de dirigir os destinos da Escola de Educação Física, visando:

a) elevar e consolidar o ensino de graduação (ponto fundamental da estrutura docente) através da criação do curso de bacharelado; ampliar as atividades da pósgraduação "sensu lato" incentivar os cursos de aperfeiçoamento nas áreas de interesse da Educação Fisica, atividades vitais para elevar o padrāo técnico-científico da Instituição e base sólida de uma pós-graduação que realmente propicie a formação de docentes e pesquisadores de elevado nível;

b) ampliar racionalmente a pesquisa objetiva e de nível na área do conhecimento, dando prioridade a linhas definidas de pesquisa e, secundariamente, a projetos isolados;

c) integrar docentes e discentes nas atividades curriculares e extracurriculares, principalmente no que concerne à prática profissional e à pesquisa; d) ampliar a já considerável extensāo de serviços à comunidade, porém sempre condicionando-a ao interesse do ensino $e$ nāo hipertrofiando-a a ponto de sobrepô-la aos interesses didáticos e de pesquisa;

e) outro aspecto fundamental a ser dimensionado é o do regime de tempo integral. Deve ser um regime estimulado, mas reservado aos que de fato têm estado de espírito e motivação para exercê-lo adequadamente. Estou plenamente convencido de que para as áreas profissionais o Turno Completo (RTC) é o que melhor se adapta às nossas necessidades. Acredito que a situação ideal é a existência em um mesmo Departamento de docentes nos dois regimes de trabalho. Evidentemente as condições salariais e ambientais são fatores que interferem no desempenho dos docentes e todos os esforços devem ser feitos no sentido de termos melhores condiçōes de trabalho.

f) reverter a imagem do docente, reformulando o conceito de professor-funcionário. $O$ que define a identidade de uma pessoa não é ao meu ver o que ela objetivamente realiza, mas sim sua concepção íntima das coisas. Com o advento da era imediatista, o indivíduo passou a ser definido pela sua produção e sua identidade pela função. A pessoa praticamente desapareceu, reduzindo-se a um conjunto de funções definidas na sociedade. Daí a di- 
ferença entre o professor educador dotado de sensibilidade, habitando um mundo interior sem limites nitidos, consubstanciado por suas paixões, esperanças e o professor comum, fruto de valores atuais de nossa sociedade, transformado num verdadeiro funcionário desmotivado de um sistema gerencial onde recebe um salário, tem $\mathrm{CIC}, \mathrm{RG}$ e outros números, adquire direitos, vantagens, escreve relatórios e quantifica os estudantes.

É difícil avaliar o ensino, ao contrário da pesquisa, que pode ser quantificada pelo número de trabalhos publicados em revistas especializadas no estrangeiro (mais valorizadas), número de livros escritos e participação em eventos científicos. As atividades de pesquisa e administrativas são inquestionavelmente importantes, contudo, na dinâmica universitária pesam exageradamente para um docente ganhar concursos, conseguir promoções e acesso à administração e gerência de projetos. Mas e o ensino, como avaliá-lo? Através do número frio de aulas dadas? Neste caso, o professor-itinerante seria o verdadeiro paradigma? 0 fato é que ainda não dispomos de critérios para avaliação da atividade docente e, talvez por isso, uma fundamental atividade não tenha ainda um valor importante nos concursos docentes;

Considero extremamente válida a preocupação de que deve haver, na USP, uma profunda reforma de seu estatuto, que possibilite completa reestruturação da carreira universitária, que deve ser feita em etapas, gradualmente, por mérito, e não através de condições que possibilitem acesso rápido sem capacitação e, o que é pior, sem a desejada vocação para a docência e a pesquisa. Estejam certos de que somarei esforços aos daqueles que pretendem dotar a USP de um Estatuto realmente adequado à grandeza desta Instituição e que espalhe sua tradição e experiência ímpar no ensino superior do país e não leve em conta ambientes e condiçōes cooperativistas que infelizmente constituem o embasamento das normas regimentais da maioria das Instituições Universitárias do país. Devemos ter sempre em mente:

O meio mais eficaz para destruir uma lei é começar simplesmente por aceitá-la, aceitar algo como mal necessário é o começo de sua eliminação. (UNAMUNO)

Peço escusas por rne alongar demasiado em conceitos tão palpitantes e aos presentes, em especial aos componentes da Escola de Educação Física da Universidade de São Paulo, lembro o pensamento de Calderon: "Deus defende minha causa, pois eu defendo a sua."

Estou certo que receberei do corpo docente, discente e administrativo da Escola de Educação Física todo o apoio pois, incondicionalmente, defenderei seus anseios e acalentarei seus mais elevados sonhos.

A todos agradeço o prestígio e a homenagem de suas presenças. 